\title{
Pharmacodynamic Effects of Beta-Adrenergic Receptor Blockade in Patients with Hyperthyroidism *
}

\author{
William R. Wilson, Ernest O. Theilen, and Fred W. Fletcher \\ (From the Section of Clinical Pharmacology and the Cardiovascular Research Laboratories, \\ Department of Internal Medicine, State University of Iowa, Iowa City, Ioz'a)
}

The interrelationships of thyroid hormone, the adrenal medulla, and the sympathetic nervous system have been recognized since the early part of the present century (1-4). More recent studies of experimental hyperthyroidism by Brewster, Isaacs, Osgood, and King (5) supported the hypothesis that the sympathetic nervous system may be responsible for the metabolic and hemodynamic changes associated with the hypermetabolic state, since the alterations induced by thyroid feeding could be reversed by epidural block.

Recent trials of reserpine $(6,7)$ and guanethidine (7-9) that release catecholamines and deplete the tissues of them have shown that these drugs can partially alleviate some clinical manifestations of thyrotoxicosis. The cardiac rate may be slowed, but consistent and significant reductions of the high cardiac output in patients with hyperthyroidism have not been reported, except by Goldstein, Furth, Becker, and Killip (10) using guanethidine. Methyldopa, a decarboxylase inhibitor, also slows the pulse rate of patients with hyperthyroidism, but does not significantly change the clinical manifestations (11), or reduce the elevated cardiac output or oxygen consumption (12). Furthermore, a continuous infusion of phentolamine (Regitine) in a hyperthyroid patient does not alter cardiac output (13), since it blocks alpha- rather than beta-adrenergic receptors. If the sympathetic nervous system is a crucial mediator of the hemodynamic changes in hyperthyroidism, it seems logical to explore the part that beta

\footnotetext{
* Submitted for publication March 16, 1964; accepted April 23, 1964.

This study was presented in part at the Annual Meeting of the Midwestern Section of the American Federation for Clinical Research, Chicago, Ill., October 31, 1963. (Clin. Res. 1963, 11, 300.) It was supported by grants from the Iowa Heart Association and the $\mathrm{Na}$ tional Heart Institute (U. S. Public Health Service grant 5T1-HE-5577-02).
}

receptor activity plays in the accelerated cardiac output and the tachycardia. The purpose of this paper is to present our observations on the pharmacodynamic effects of nethalide (2-isopropylamino-1-[2-naphthyl] ethanol hydrochloride), a drug that blocks beta-adrenergic receptors in patients with spontaneous hyperthyroidism.

\section{Methods}

All patients studied were from the wards of the University Hospitals, Iowa City. There were seven women and four men. They ranged in age from 19 to 54 years (mean, 32.5) and in body surface area from 1.40 to 1.83 $\mathrm{m}^{2}$ (mean, 1.65). All had classic manifestations of hyperthyroidism but no signs of heart failure or arrhythmia. The protein-bound iodine averaged $13.1 \mu \mathrm{g}$ per $100 \mathrm{ml}$ serum, and the 24-hour uptake of $\mathrm{I}^{131}$ varied from 56 to $92 \%$ (mean, $72.8 \%$ ). No patient had received antithyroid drugs for at least 1 month before these studies. Each patient received a 2,500 calorie diet.

Hemodynamic responses to beta-adrenergic receptor stimulation by isoproterenol hydrochloride were recorded in seven hyperthyroid patients before and after nethalide (1 $\mathrm{mg}$ per $\mathrm{kg}$ iv). Heart rate, cardiac output, and systemic arterial and mean right atrial pressures were recorded before and during the fourth minute of infusion of isoproterenol at two dose levels, before and 10 minutes after nethalide. Isoproterenol was given at rates of 0.025 and $0.05 \mu \mathrm{g}$ per $\mathrm{kg}$ per minute by a constant speed infusion pump. An adequate amount of time (10 to 15 minutes) was allowed to pass between the first two isoproterenol infusions to allow the heart rate, pressures, and cardiac output to return to control levels; an equal period was allowed before the intravenous nethalide ( 1 mg per $\mathrm{kg}$ ) was given. Nethalide was diluted with $10 \mathrm{ml}$ of sterile water and given through the right atrial catheter at a rate of $10 \mathrm{mg}$ per minute. The studies were repeated in six of these patients and in one additional hyperthyroid patient 3 to 7 days after oral administration of nethalide ( 600 to $800 \mathrm{mg}$ per day). The beta-adrenergic blocking drug was given in four equal doses at intervals of 6 hours. Oxygen consumption was measured before and after oral nethalide. Three other hyperthyroid patients had similar studies before and after an equal volume of isotonic saline intravenously and after 


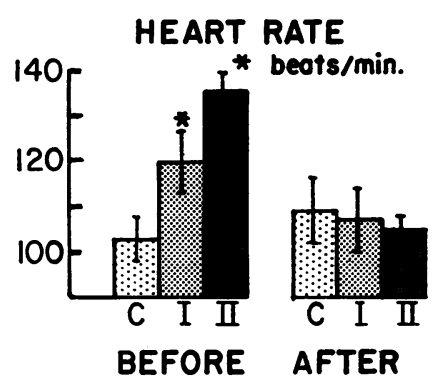

MEAN ARTERIAL PRESSURE

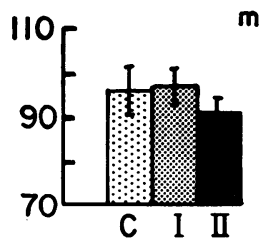

$\mathrm{mm} . \mathrm{Hg}$

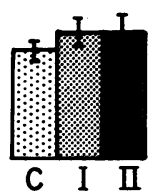

CARDIAC INDEX

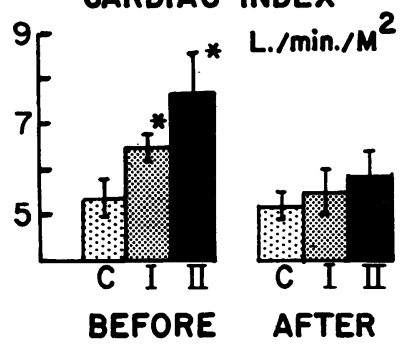

MEAN RT. ATRIAL PRESSURE

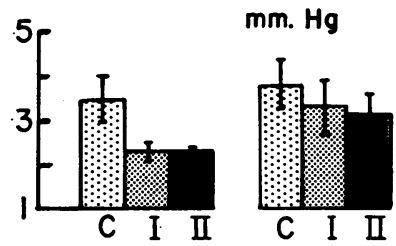

Fig. 1. EFFECtS OF isoproterenol in SEven hyperthyroid patients BeFORE AND 10 minutes After intravenous Nethalide ( 1 Mg PER KG). C refers to control measurements. I refers to measurements made during the 4th minute of infusion of isoproterenol $(0.025 \mu \mathrm{g}$ per $\mathrm{kg}$ per minute). II refers to measurements made during the 4 th minute of infusion of isoproterenol $(0.05 \mu \mathrm{g}$ per $\mathrm{kg}$ per minute). The asterisks indicate values significantly different from control measurements. Each bar represents a mean value $( \pm S E)$.

oral nethalide placebos to assay the effect of elapsed time on the hemodynamic responses.

Each patient was in a fasting state on the day of study. No sedative was given. Measurements were made with the patient in the supine position. A small catheter was introduced through the basilic vein and advanced until its tip was lying free within the right atrium. A Cournand needle was placed in a brachial artery. Pressures were recorded from the right atrium and brachial artery with Statham strain gauges. Mean pressures were obtained by electrical integration. Pressure recordings were made immediately before cardiac output determinations. The catheter in the right atrium was filled with indocyanine green dye and connected through a threeway stopcock to a dye reservoir and injection system. The needle in the brachial artery was connected through a short, small-bore, polyethylene tube to the cuvette of a Gilford densitometer. One $\mathrm{ml}$ of blood was added to each ampoule of dye to bind dye to albumin to avoid errors in calibration by adsorption of dye on tubing or glassware. Approximately $2.8 \mathrm{mg}$ of dye was used for each injection. Dye was injected into the right atrium, and dye curves were obtained by drawing arterial blood through the densitometer with a constant speed pump at a rate of $30 \mathrm{ml}$ per minute. Three-point calibration curves were made in each study. Cardiac output was calculated by the Stewart-Hamilton method. Total peripheral resistance was calculated in terms of dynessec- $\mathrm{cm}^{-5}$. Lead II of an electrocardiogram was recorded during each cardiac output determination in order to measure heart rate. Dye curves, heart rates, and blood pressures were recorded with a Sanborn direct-writing oscillograph. Duplicate measurements of output and pressures were made during the control periods before and after nethalide. Expired air was collected in a Tissot spirometer for 3 minutes for determination of oxygen consumption. Two measurements were made before and after oral nethalide. All values for oxygen consumption are given in terms of standard conditions $\left(0^{\circ} \mathrm{C}\right.$ and $760 \mathrm{~mm} \mathrm{Hg}$, dry).

Student's $t$ test for paired data was used for comparisons of the control and isoproterenol data before and after nethalide (14). In this study a p value of $<0.05$ was the criterion for statistical significance.

\section{Results}

General. The infusions of isoproterenol were well tolerated by all of the patients. Many of them were aware of palpitation and pounding of the heart, especially during infusion of the larger dose of isoproterenol. These symptoms did not occur during either of the infusions of isoproterenol after intravenous or oral administration of nethalide. Nervousness, tremor, ocular signs, and other clinical manifestations of spontaneous hyperthyroidsm were not affected by beta-adrenergic receptor blockade. 
TABLE I

Effects of nethalide in patients with hyperthyroidism*

\begin{tabular}{|c|c|c|}
\hline $\begin{array}{l}\text { A. Hyperthyroid patients } \\
\text { Nethalide, } 1 \mathrm{mg} / \mathrm{kg} \text { iv } \\
\text { (no. }=7 \text { ) }\end{array}$ & $\begin{array}{l}\text { Pretreatment levels } \\
\pm \mathrm{SE}\end{array}$ & $\begin{array}{l}10 \text { minutes after } \\
\text { nethalidet } \pm \mathrm{SE}\end{array}$ \\
\hline $\begin{array}{l}\text { Heart rate, beats } / \mathrm{min} \\
\text { Cardiac index, } \mathrm{L} / \mathrm{min} / \mathrm{m}^{2} \\
\text { Systemic mean arterial pressure, } \mathrm{mm} \mathrm{Hg} \\
\text { Mean right atrial pressure, } \mathrm{mm} \mathrm{Hg} \\
\text { Total systemic resistance, dyne-sec-cm }\end{array}$ & $\begin{array}{l}103 \pm 5.9 \\
5.4 \pm 0.4 \\
96 \pm 5.6 \\
3.5 \pm 0.5 \\
940 \pm 96\end{array}$ & $\begin{array}{l}109 \pm 6.8 \\
5.2 \pm 0.3 \\
95 \pm 1.7 \\
3.8 \pm 0.5 \\
930 \pm 48\end{array}$ \\
\hline $\begin{array}{l}\text { B. Hyperthyroid patients } \\
\text { Nethalide, } 600-800 \mathrm{mg} / \text { day orally } \\
\text { (no. }=7 \text { ) }\end{array}$ & $\begin{array}{l}\text { Pretreatment levels } \\
\pm \mathrm{SE}\end{array}$ & $\begin{array}{l}\text { After } 3 \text { to } 7 \text { days } \\
\text { of nethalidet }\end{array}$ \\
\hline $\begin{array}{l}\text { Heart rate, beats } / \mathrm{min} \\
\text { Cardiac index, } \mathrm{L} / \mathrm{min} / \mathrm{m}^{2} \\
\text { Systemic mean arterial pressure, } \mathrm{mm} \mathrm{Hg} \\
\text { Mean right atrial pressure, } \mathrm{mm} \mathrm{Hg}^{-} \\
\text {Peripheral resistance, dyne-sec-cm } \\
\text { Oxygen consumption, } \mathrm{ml} / \mathrm{min} / \mathrm{m}^{2}\end{array}$ & $\begin{array}{l}103 \pm 5.0 \\
5.3 \pm 0.4 \\
95 \pm 4.9 \\
3.5 \pm 0.6 \\
935 \pm 81 \\
183 \pm 19\end{array}$ & $\begin{array}{l}100 \pm 3.9 \\
5.3 \pm 0.3 \\
95 \pm 2.4 \\
4.2 \pm 0.6 \\
885 \pm 36 \\
189 \pm 9\end{array}$ \\
\hline
\end{tabular}

* Six of the hyperthyroid patients who received nethalide (iv) (A) and one additional hyperthyroid patient were studied again af ter oral nethalide $(B)$.

$\dagger$ Nethalide, given iv or orally, produced effective beta-adrenergic blockade (Figures 1, 2), but did not alter the cardiac hemodynamics or the oxygen consumption of these hyperthyroid patients. None of the postdrug values was significantly different from control.

Effects of isoproterenol before and after intravenous nethalide. The effects of isoproterenol on heart rate, cardiac index, and systemic mean arterial and mean right atrial pressures before and after administration of nethalide (1 $\mathrm{mg}$ per $\mathrm{kg}$ iv) are shown in Figure 1. Before nethalide, isoproterenol at the two dose levels significantly increased heart rate from an average of 103 to 120 and 136 beats per minute, respectively. After nethalide, the mean heart rate varied from a control rate of 109 to 107 and 105 beats per minute in response to the two dose levels of isoproterenol, respectively. Thus nethalide abolished the positive chronotropic effects of isoproterenol. The average control cardiac index was $5.4 \mathrm{~L}$ per minute per $\mathrm{m}^{2}$; the infusions of isoproterenol significantly increased the cardiac index to 6.5 and $7.7 \mathrm{~L}$. After nethalide, isoproterenol did not induce appreciable increases in cardiac output. The average control cardiac index after the blocking agent was $5.2 \mathrm{~L}$ per minute per $\mathrm{m}^{2}$; during the two infusions of isoproterenol it increased to 5.5 and $5.9 \mathrm{~L}$ per minute per $\mathrm{m}^{2}$. The systemic mean arterial pressure averaged $97 \mathrm{~mm} \mathrm{Hg}$ before the betablocker was given. It did not change appreciably during isoproterenol infusions either before or after nethalide. Since pressure did not vary and flow increased, calculated total systemic resistance decreased significantly during isoproterenol infusions. After nethalide, this effect was blocked. Mean right atrial pressure before the beta-adrenergic blocking drug averaged $3.5 \mathrm{~mm} \mathrm{Hg}$ (in five of seven subjects in which it was measured). It tended to fall during isoproterenol infusions in each subject, but the changes were not of sufficient magnitude to achieve statistical significance as defined for this study (actual $\mathrm{p}$ value $<0.10$ ). After nethalide this reduction in right atrial pressure during isoproterenol tended to be less. Heart rate, cardiac output, and systemic mean arterial and right atrial pressures after nethalide were not significantly different from their respective controls, although effective beta-receptor blockade had been induced (Figure 1 and Table I).

Effects of isoproterenol before and after oral nethalide. Figure 2 shows the effects of isoproterenol on heart rate, cardiac index, and systemic mean arterial and mean right atrial pressures before and after 3 to 7 days of nethalide, given orally, 600 to $800 \mathrm{mg}$ per day, in four doses at intervals of 6 hours. Before nethalide isoproterenol increased heart rate from 103 to 119 and 129 beats per minute, and cardiac index from 5.3 to 6.3 and $7.2 \mathrm{~L}$ per minute per $\mathrm{m}^{2}$, respectively. After beta-adrenergic receptor blockade, the larger dose of isoproterenol produced a small and statisti- 

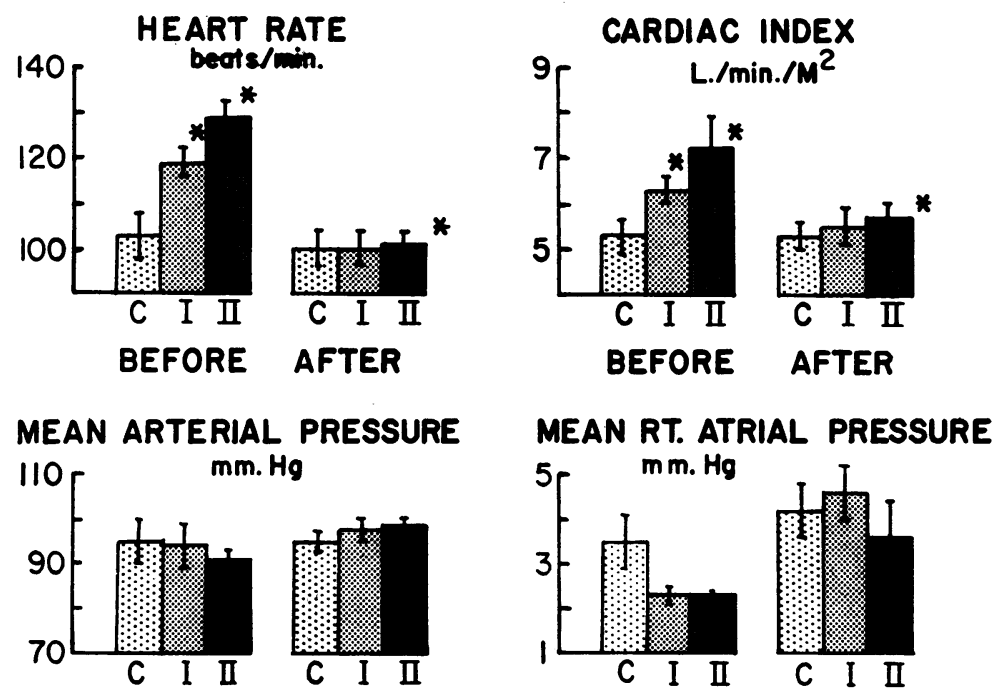

Fig. 2. EFfects OF isoproterenol before AND After ORAL Nethai.ide ( 600 TO 800 MG PER DAY IN FOUR EQUAL DOSES AT INTERVALS OF 6 HOURS, FOR 5 TO 7 DAYs). See legend for Figure 1. The changes in heart rate and cardiac index after the beta-blocker are significantly less than before the drug.

cally significant increase in heart rate and cardiac index, but these increases were significantly less than before nethalide. The responses of systemic mean arterial and mean right atrial pressures to beta-adrenergic receptor stimulation by isopro- terenol were not appreciably altered by nethalide. Once again beta-adrenergic receptor blockade abolished the significant reduction in total peripheral resistance that occurred during infusions of isoproterenol. Despite effective beta-adrenergic

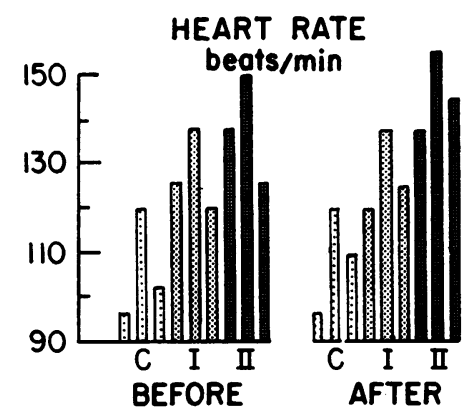

\section{CARDIAC INDEX \\ $L / \min . / M^{2}$}
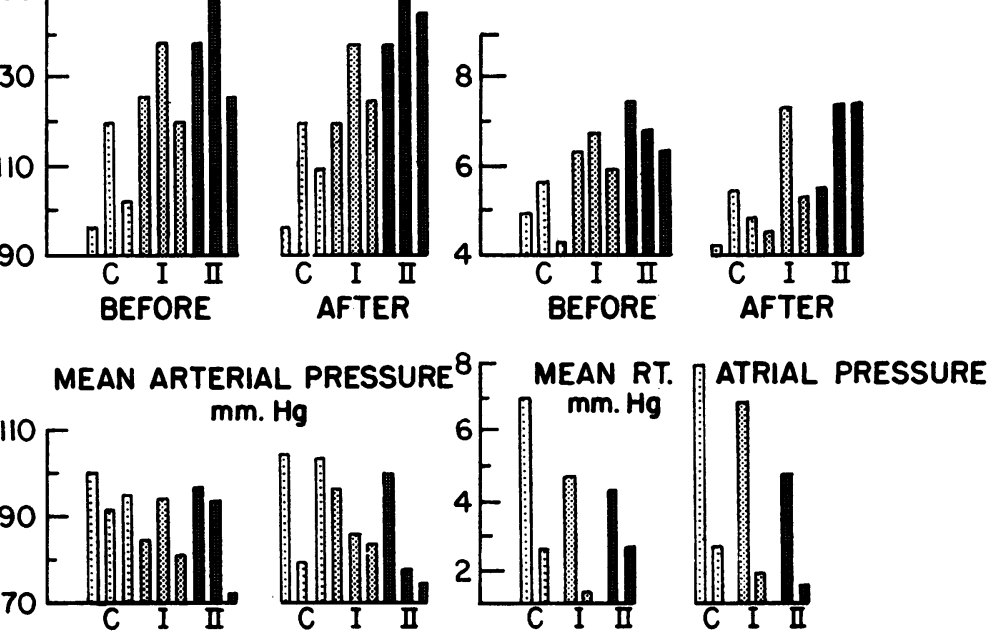

Fig. 3. EFFECTS OF ISOPROTERENOL BEFORE AND AFTER ISOTONIC SALINE (10 ML IV). See legend for Figure 1. Individual measurements are shown for three patients to show that the blocking effects of nethalide (Figure 1) were not related to time alone. Right atrial pressure was measured in two patients only. Responses are in the same order in each period (C, I, II). 

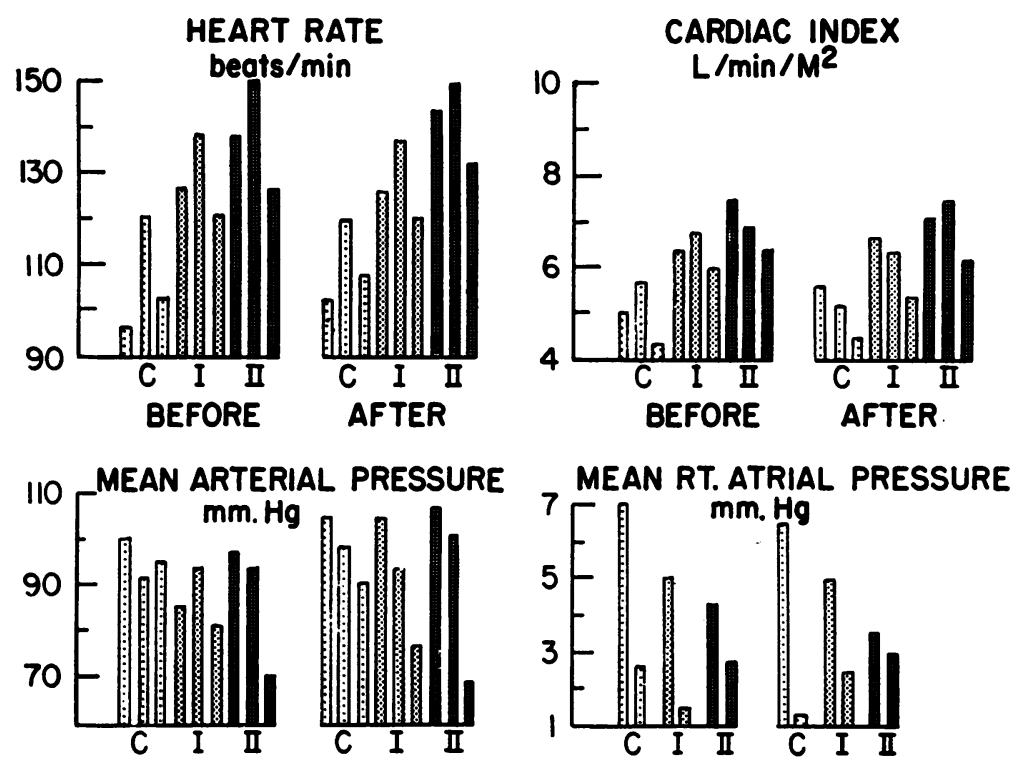

Fig. 4. EFFects of isoproterenol before AND AFTER ORAL NETHALIDE PLACEBo (GIVEN FOR 3 DAYs). See legend for Figures 1 and 3 . Individual effects are shown for three patients to assay the effect of time, except for mean right atrial pressure (two patients).

receptor blockade, nethalide alone did not alter the average control heart rate, cardiac index, and systemic mean arterial or mean right atrial pressures (Figure 2 and Table I).

Placebo effects, acute and chronic. The effects of isoproterenol on the individual heart rates, cardiac indexes, and mean arterial and mean right atrial pressures of three additional patients before, 10 minutes after intravenous infusion of $10 \mathrm{ml}$ of isotonic saline solution, and 3 days after oral administration of nethalide placebos at intervals of 6 hours, are shown in Figures 3 and 4. Responses to isoproterenol after the placebos were similar to those obtained in the control period regardless of the route of administration.

Effect of nethalide on oxygen consumption. Table I shows the lack of effect of oral nethalide on the mean oxygen consumption of six hyperthyroid patients. The mean oxygen consumption before beta-adrenergic receptor inhibition was 183 $\mathrm{ml}$ per minute per $\mathrm{m}^{2}$; after nethalide it was 189 $\mathrm{ml}$ per minute per $\mathrm{m}^{2}$.

\section{Discussion}

These results clearly indicate that in the doses used in this study ( $1 \mathrm{mg}$ per $\mathrm{kg}$ iv or 600 to 800 mg per day orally) nethalide can produce effective beta-adrenergic receptor blockade in patients with hyperthyroidism. Nethalide was first shown to be an effective antagonist of beta-adrenerigc receptors by Black and Stephenson (15). They reported that it blocked the increase in heart rate produced by infusion of catecholamines and that it had no intrinsic sympathomimetic activity. Bradycardia was common in unanesthetized animals and was attributed to myocardial adrenergic blockade. Dornhorst and Robinson (16) showed that the heart rate usually is slowed by the drug at rest and always on exercise in normal man and in patients with ischemic heart disease. Harrison and co-workers (17) demonstrated beta-adrenergic receptor blockade with nethalide (1.5 mg per $\mathrm{kg}$ iv) in 15 euthyroid patients; 10 of his group had hypertrophic subaortic stenosis, and the others had approximately normal circulatory dynamics. Nethalide produced a small but statistically significant reduction in heart rate in the resting state and attenuated the increases in heart rate associated with exercise as well as the responses to graded doses of isoproterenol. Cardiac output at rest and in response to exercise was not appreciably changed by nethalide.

Beta-adrenergic receptor blockade in hyper- 
thyroid patients was demonstrated in the present study by inhibition or by marked attenuation of the normal increases in heart rate and cardiac output during infusions of isoproterenol. We cannot necessarily infer from these results, however, that beta-adrenergic stimulation by endogenous catecholamines was blocked. The increase in heart rate and augmentation of myocardial contractility and peripheral vasodilatation in response to isoproterenol are thought to be mediated through beta-adrenergic receptors. If the sympathetic nervous system is the important mediator of the effects of excess thyroid hormone, it would be logical to postulate that enhanced function of betaadrenergic receptors might be responsible for the circulatory abnormalities in hyperthyroidism. Although nethalide produced effective beta-receptor blockade in these patients it had no effect on heart rate or cardiac output. These findings do not support the concept that the hemodynamic effects of thyroid hormone are mediated through the sympathetic nervous system. Harrison and associates (17) suggested that tonic sympathetic activity is not of great importance in the regulation of the circulation in basal subjects in the supine position. These authors and others (18, 19) have stressed its important influence in mediating the circulatory response to exercise in man. The resting hyperthyroid patient, however, cannot be compared with a basal normal subject, since the circulatory responses to hyperthyroidism resemble the reactions of a normal person to strenuous exercise.

What then is the explanation for the basic circulatory changes in the thyrotoxic patient? The "exaggerated" response of thyrotoxic patients to exogenous pressor amines does not necessarily imply that the effects of thyroid hormone are mediated directly by action of this hormone on the sympathetic nervous system and its adrenergic receptors. Perhaps the only difference between the thyrotoxic patient and the normal subject in response to catecholamines is the level of the starting point rather than the increments in heart rate and cardiac output. Uncoupling of oxidative phosphorylation is said to occur in thyrotoxicosis. Impaired oxygen utilization could produce relative tissue hypoxia. Hypoxia and perhaps accumulation of certain metabolites might induce vasodilatation in the peripheral tissues. Such a phenomenon if of sufficient magnitude could activate baroreceptor and other neural or humoral reflexes leading to an increased heart rate and increased cardiac output to maintain homeostasis. Such considerations do not exclude the possibility of direct effects of thyroid hormone on the sinus node or other cardiac tissues.

\section{Summary}

Effective beta-adrenergic receptor blockade by nethalide, given intravenously or orally, was produced in patients with hyperthyroidism. Despite inhibition of the chronotropic and inotropic effects of isoproterenol, nethalide did not significantly change oxygen consumption, heart rate, cardiac output, and systemic mean arterial or mean right atrial pressures in these patients. These findings do not support the hypothesis that the hemodynamic changes in hyperthyroidism are mediated through adrenergic stimulation of beta-adrenergic receptors.

\section{Acknowledgment}

Generous supplies of nethalide and placebos were obtained from Dr. Sahagian-Edwards, Ayerst Laboratories, New York, N. Y.

\section{References}

1. Eppinger, H., W. Falta, and C. Rudinger. Ueber die Wechselwirkungen der Drüsen mit inner Sekretion. Z. klin. Med. 1908, 66, 1.

2. Cannon, W. B., and M. Cattell. Studies on the conditions of activity in endocrine glands. III. The influence of the adrenal secretion on the thyroid. Amer. J. Physiol. 1916, 41, 74.

3. Levy, R. L. Studies on the conditions of activity in endocrine glands. IV. The effect of thyroid secretion on the pressor action of adrenin. Amer. J. Physiol. 1916, 41, 492.

4. Goetsch, E. Newer methods in the diagnosis of thyroid disorders: pathological and clinical. N. Y. St. J. Med. 1918, 18, 259.

5. Brewster, W. R., Jr., J. P. Isaacs, P. A. Osgood, and T. L. King. The hemodynamic and metabolic interrelationships in the activity of epinephrine, norepinephrine and the thyroid hormones. Circulation 1956, 13, 1.

6. Canary, J. J., M. Schaaf, B. J. Duffy, Jr., and L. H. Kyle. Effects of oral and intramuscular administration of reserpine in thyrotoxicosis. New Engl. J. Med. 1957, 257, 435.

7. DeGroot, W. J., J. J. Leonard, H. W. Paley, J. E. Johnson, and J. V. Warren. The importance of 
autonomic integrity in maintaining the hyperkinetic circulatory dynamics of human hyperthyroidism (abstract). J. clin. Invest. 1961, 40, 1033.

8. Gaffney, T. E., E. Braunwald, and R. L. Kahler. Effects of guanethidine on tri-iodothyronine-induced hyperthyroidism in man. New Engl. J. Med. 1961, 265, 16.

9. Lee, W. Y., D. Bronsky, and S. S. Waldstein. Studies of thyroid and sympathetic nervous system interrelationships. II. Effects of guanethidine on manifestations of hyperthyroidism. J. clin. Endocr. 1962, 22, 879.

10. Goldstein, S., E. D. Furth, D. V. Becker, and T. Killip. III. Effect of guanethidine on the cardiovascular and metabolic manifestations of thyrotoxicosis (abstract). Circulation 1962, 26, 721.

11. Levine, R. J., J. A. Oates, A. Vendsalu, and A. Sjoerdsma. Studies on the metabolism of aromatic amines in relation to altered thyroid function in man. J. clin. Endocr. 1962, 22, 1242.

12. Theilen, E. O., W. R. Wilson, and F. J. Tutunji. The acute hemodynamic effects of alpha-methyldopa in thyrotoxic patients and normal subjects. Metabolism 1963, 12, 625.
13. Wilson, W. R., and E. O. Theilen. Unpublished observations.

14. Snedecor, G. W. Statistical Methods Applied to Experiments in Agriculture and Biology, 5th ed. Ames, Iowa, State College Press, 1956, p. 46.

15. Black, J. W., and J. S. Stephenson. Pharmacology of a new adrenergic beta-receptor-blocking compound (nethalide). Lancet 1962, 2, 311.

16. Dornhorst, A. C., and B. F. Robinson. Clinical pharmacology of a beta-adrenergic-blocking agent (nethalide). Lancet 1962, 2, 314.

17. Harrison, D. C., E. Braunwald, G. Glick, D. T. Mason, C. A. Chidsey, and J. Ross, Jr. Effects of beta adrenergic blockade on the circulation, with particular reference to observations in patients with hypertrophic sub-aortic stenosis. Circulation 1964, 29, 84.

18. Rushmer, R. F., O. Smith, and D. Franklin. Mechanisms of cardiac control in exercise. Circulat. Res. 1959, 7, 602.

19. Kahler, R. L., T. E. Gaffney, and E. Braunwald. The effects of autonomic nervous system inhibition on the circulatory response to muscular exercise. J. clin. Invest. 1962, 41, 1981. 